\title{
Endoscopic mucosal resection of an oesophageal carcinoid tumour
}

\author{
John K Eccles, ${ }^{1}$ Damian T McManus, ${ }^{2}$ Inder Mainie ${ }^{1}$
}

'Department of

Gastroenterology, Belfast City Hospital, Belfast, Antrim, UK ${ }^{2}$ Department of Histopathology, Belfast City Hospital, Belfast, Antrim, UK

\section{Correspondence to}

Dr John K Eccles,

johnkeccles@doctors.org.uk

\section{DESCRIPTION}

A 59-year-old female with Sjogren's disease presented with progressive dysphagia and intermittent retrosternal discomfort. She underwent an oesophago-gastro-duodenoscopy, which identified an oesophageal lesion at $30 \mathrm{~cm}$ from the incisors (figure 1). Histopathological analysis demonstrated a nested proliferation of bland epithelioid cells deep to the intact squamous mucosal surface. Staining showed positivity for the cytokeratins, CAM 5.2 and $\mathrm{AE} 1 / 3$, as well as for the neuroendocrine synaptophysin, but negativity for chromogranin. It was felt that the most likely diagnosis was a welldifferentiated neuroendocrine tumour. An octreotidesomatostatin receptor study did not demonstrate any abnormal increased uptake within the oesophagus or

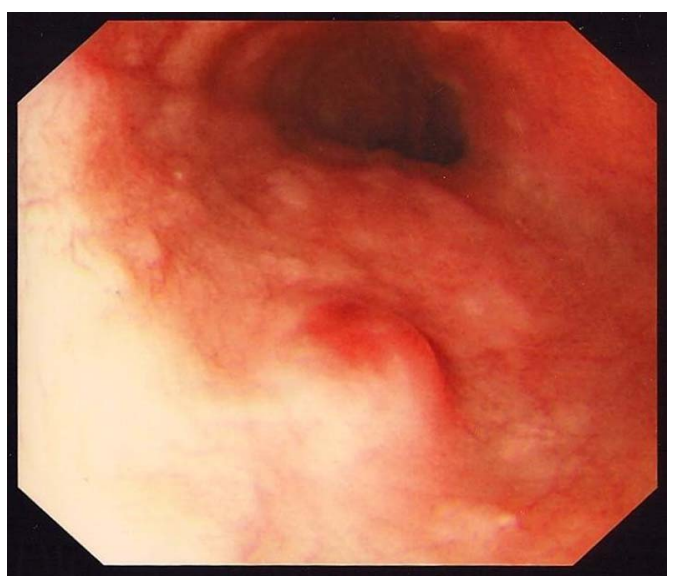

Figure 1 Lesion identified on oesophagoscopy at $30 \mathrm{~cm}$ from the incisors.

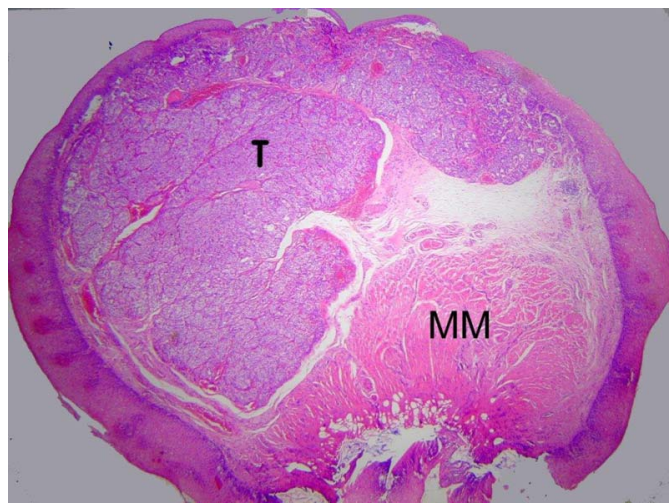

Figure 2 Histopathological specimen following endoscopic mucosal resection showing tumour margin at $2 \mathrm{~mm}$ from the diathermied base of excision. T, tumour; MM, muscularis mucosae. evidence of metastatic disease. Following discussion at the neuroendocrine multidisciplinary meeting, the patient was referred for endoscopic ultrasonography. This confirmed that the lesion was contained within the submucosa, with no extension into the muscularis propia. Endoscopic mucosal resection of the tumour was carried out, with application of three endoscopic clips for delayed bleeding. The tumour was found to measure $3 \mathrm{~mm}$ in its maximum diameter, and was $2 \mathrm{~mm}$ from the diathermied base of excision, with a nested proliferation of bland tumour cells with no cytological atypia, and some clearing of the cytoplasm was noted (figure 2). The appearances were felt to be in keeping with a carcinoid tumour of the oesophagus.

\section{Learning points}

- Carcinoid tumours are a subgroup of neuroendocrine tumours that arise from enterochromaffin cells, with the vast majority occurring within the midgut, particularly the appendix or ileum. Carcinoid tumours of the foregut are less common, usually involving the lung, stomach or duodenum; however, carcinoid tumours of the oesophagus are remarkably rare. Unfortunately, many patients present at an advanced stage, with extensive metastatic disease precluding curative surgery.

- Although endoscopic mucosal resection of small gastric and duodenal carcinoid tumours has been recognised as a treatment modality in several cases within the literature, there are only a few reports, to our knowledge, in which an oesophageal carcinoid tumour has been identified, or removed this way. ${ }^{1-3}$

- This case clearly demonstrates the importance of a multidisciplinary approach in determining a patient-centred treatment strategy. Through the appropriate use of endoscopic ultrasound in this patient's case it was demonstrated that this rare carcinoid tumour had not extended beyond the submucosa and could therefore be curatively resected endoscopically without the need for major surgery and any associated morbidity or risk of mortality.

\section{Competing interests None.}

Patient consent Obtained.

Provenance and peer review Not commissioned; externally peer reviewed. 


\section{REFERENCES}

1 Babich JP, Klein J, Khullar $P$, et al. Endoscopic mucosal resection of a mid-oesophageal carcinoid with EUS guidance. Endoscopy 2010;42(Suppl 2):E302-3.

2 Gupta NM, Goenka MK, Atri A, et al. Carcinoid tumour of the oesophagus: a rare oesophageal cancer. Eur J Surg 1996;162:841-4. PMID:8934118
3 Cary NR, Barron DJ, McGoldrick JP, et al. Combined oesophageal adenocarcinoma and carcinoid in Barrett's oesophagitis: potential role of enterochromaffin-like cells in oesophageal malignancy. Thorax 1993:48:404-5. PMID: 8511743

Copyright 2013 BMJ Publishing Group. All rights reserved. For permission to reuse any of this content visit http://group.bmj.com/group/rights-licensing/permissions.

BMJ Case Report Fellows may re-use this article for personal use and teaching without any further permission.

Become a Fellow of BMJ Case Reports today and you can:

- Submit as many cases as you like

- Enjoy fast sympathetic peer review and rapid publication of accepted articles

- Access all the published articles

- Re-use any of the published material for personal use and teaching without further permission

For information on Institutional Fellowships contact consortiasales@bmjgroup.com

Visit casereports.bmj.com for more articles like this and to become a Fellow 